\title{
TRANSPARANSI, AKUNTABILITAS DAN PARTISIPASI DALAM PENGELOLAAN APB NAGARI DI KECAMATAN KAMANG MAGEK
}

\author{
MERCYA VAGUITA ${ }^{1}$, HILDA OKTRI YENI ${ }^{2}$ \\ Prodi Ilmu Administrasi Negara, STISIP Imam Bonjol Padang, Padang ${ }^{1}$, Prodi Pendidikan \\ Jasmani Kesehatan dan Rekreasi, Universitas Karimun ${ }^{2}$ \\ mercyavaguita@gmail.com¹, hildaoktriyeni@gmail.com²
}

\begin{abstract}
The purpose of this study was to find out the management of local government budget in Kamang Magek Subdistrict, Agam Regency. This research is a descriptive analysis using a qualitative approach that uses primary data and secondary data. The technique of collecting data is in the form of field research by means of interviews, focus group discussions $(F G D)$, and documentation studies with valid and accurate sources. The results of the study showed that the management of local government budget has not fully run well this is because there are still obstacles faced in accordance with Permendagri Number 113 of 2014 and Perbub Agam Number 8 of 2017. (1) Implementation of the principle of transparency consists of indicators, namely openness in meetings, openness of information, openness of procedures, and openness in accepting community participation. (2) Implementation of the principle of participation consists of indicators, namely the existence of active public participation, the existence of regulations that provide a place for community control, and the presence of proactive attitudes of regional governments in the budgeting process. (3) Implementation of the principle of accountability consists of indicators, namely the existence of honesty and legal accountability, the existence of process accountability, the existence of program accountability, and the existence of policy accountability.
\end{abstract}

Keywords: Transparency, Accountability, Participation, APB Nagari.

Abstrak: Tujuan dari penelitian ini adalah untuk mengetahui pengelolaan anggaran pemerintah daerah di Kecamatan Kamang Magek Kabupaten Agam. Penelitian ini merupakan penelitian deskriptif analisis dengan menggunakan pendekatan kualitatif yang menggunakan data primer dan data sekunder. Teknik pengumpulan data berupa penelitian lapangan dengan cara wawancara, focus group discussion (FGD), dan studi dokumentasi dengan sumber yang valid dan akurat. Hasil penelitian menunjukkan bahwa pengelolaan APBD belum sepenuhnya berjalan dengan baik hal ini dikarenakan masih adanya kendala yang dihadapi sesuai dengan Permendagri Nomor 113 Tahun 2014 dan Perbub Agam Nomor 8 Tahun 2017. transparansi terdiri dari indikator yaitu keterbukaan dalam rapat, keterbukaan informasi, keterbukaan prosedur, dan keterbukaan dalam menerima partisipasi masyarakat. (2) Pelaksanaan asas partisipasi terdiri dari indikator, yaitu adanya partisipasi aktif masyarakat, adanya peraturan yang memberikan tempat bagi kontrol masyarakat, dan adanya sikap proaktif pemerintah daerah dalam proses penganggaran. (3) Penerapan prinsip akuntabilitas terdiri dari indikator, yaitu adanya kejujuran dan akuntabilitas hukum, adanya akuntabilitas proses, adanya akuntabilitas program, dan adanya akuntabilitas kebijakan.

Kata kunci: Transparansi, Akuntabilitas, Partisipasi, APB Nagari.

\section{A. Pendahuluan}

Undang-undang Nomor 6 Tahun 2014 tentang Desa merupakan suatu kebijakan yang membawa harapan baru bagi kesejahteraan masyarakat desa. Hal ini dikarenakan kebijakan ini menetapkan peningkatan alokasi anggaran yang lebih besar kepada desa untuk membiayai pembangunan, pelayanan, pembinaan dan pemberdayaan masyarakat desa. Terdapat adanya dana 10\% dari APBN dan APBD bagi setiap desa. Hak dan kewajiban desa ini menimbulkan pendapatan, belanja, pembiayaan, dan pengelolaan keuanga desa dengan adanya alokasi Anggaran Pendapatan dan Belanja Negara kepada Desa perlu dilaksanakan secara transparansi, akuntabel dan partisipasi dalam mengelola dana nagari secara efektif dan efisien. Dalam 
penerapan ketiga pilar ini akan menjadi kekuatan pemerintah desa untuk mengurus, mengatur, dan menyelenggarakan pengelolaan keuangan pemerintah nagari yang baik, sesuai dengan tahapan perencanaan, pelaksanaan, penatausahaan, pelaporan, dan pertanggungjawaban.

Pengelolaan APB Nagari di Kabupaten Agam masih belum berjalan dengan semestinya, sesuai dengan Permenpan Permendagri Nomor 113 Tahun 2014 dan Perbup Agam Nomor 29 Tahun 2018 tentang Pedoman Penyusunan Anggaran Pendapatan dan Belanja Nagari Tahun Anggaran 2019, ini masih saja terkendala dalam penerapannya. Sesuai dengan data awal yang penulis dapatkan, berdasarkan informasi dari Bapak Amdanir ST, Wali Nagari Kamang Mudiak, Kecamatan Kamang Magek terdapat kendala adanya keterlambatan pelaporan pertanggungjawaban, hal ini disebabkan dari sumber daya manusia yang masih belum mampu dalam mengelola APB Nagari. Selain itu, berdasarkan Kasi Perencanaan Keuangan dan Pembangunan, Dinas Pemberdayakan Masyarakat dan Pemerintah Nagari, Kabupaten Agam yaitu Bapak Eko Purwanto, menyatakan bahwa pasti ada beberapa permasalahan dalam pengelolaannya seperti kesalahan pada kode rekening dan penjumlahan penerimaan dan pengeluaran, adanya keterbatasan dana dalam pelaksanaan kegiatan dan masih ada kegiatan yang direncanakan nagari yang tidak terlaksana, hal ini disebabkan banyaknya peraturan baru, sehingga aparatur nagari terkendala dalam memahami aturan yang ada.

Dalam beberapa penelitian terdahulu, menyatakan bahwa pengelolaan keuangan masih belum sesuai dengan peraturannya, diantaranya ialah (Alfasadun, Hardiningsih, Ratnasari, \& Srimindarti, 2018; Assyahri \& Vaguita, 2019; Astuti \& Yulianto, 2016; Atmadja \& Saputra, 2018; Kadir, Widarini, Gunawan, \& Puspitasari, 2017; Meutia \& Liliana, 2017; A. Setiawan, 2018; Shuha, 2018; Supriadi, 2015; Yulihantini \& Wardayanti, 2016), menemukan permasalahan dalam pengelolaan keuangan desa diantara lain, yaitu (1) Peraturan yang tidak jelas, (2) Masih rendahnya kualitas pengelolaan keuangan desa, (3) Kurangnya koordinasi dan pengawasan, (4) Sumber daya manusia yang tidak cakap, (5) Keterlambatan pelaporan, dan Perubahan APBN.

Berdasarkan informasi dari Sekretaris Kamang Hilir, Kecamatan Kamang Magek Bapak Hanif Putra, mengatakan bahwa sudah transparan dalam realisasi pelaksanaan APB Nagari setiap tahun anggarannya, tetapi partisipasi dan akuntabilitas masih kurang dalam pelaksanaan APB Nagari, sehinga perlu dilakukan pembinaan dan pelatihan secara berkelanjutan mulai dari perencanaan hingga pelaporan pertanggungjawaban. Dalam penelitian terdahulu menyatakan bahwa transparansi, partisipasi dan akuntabilitas dalam pengelolaan APB Nagari masih ada permasalahan dalam pengelolaannya, diantaranya penelitian; (Agustin, Arza, Mulyani, \& Fitra, 2017; Armaini, 2017; Leonardo Yosua Liando, Lambey, \& Wokas, 2017; Sartika \& Nini, 2018; Vaguita \& Adnan, 2019; Yunianti, 2015)

Berdasarkan uraian sebelumnya maka penulis berpendapat perlu dilakukan kajian ilmiah terkait pengelolaan anggaran pendapatan dan belanja pemerintahan nagari di Kabupaten Agam, dengan judul sebagai berikut "Bagaimana Implementasi Transparansi, Partisipasi, dan Akuntabilitas Dalam APB Nagari di Kecamatan Kamang Magek”.

\section{B. Metedologi Penelitian}

Penelitian ini merupakan analisis deskriptif dengan menggunakan pendekatan kualitatif yang digunakan untuk menganalisis transparansi, partisipasi, akuntabilitas dalam pengelolaan (APB Nagari) di Kecamatan Kamang Magek. Informan yang digunakan dalam penelitian kualitatif ini menggunakan teknik purposive sampling, sumber yang benar-benar dapat memberikan infomasi. Informan penelitian ini terdiri dari Dinas Pemberdayaaan Masyarakat dan Pemerintah Nagari (DPMPN) Kabupaten Agam, Kecamatan Kamang Magek Kabupaten Agam, Wali Nagari serta perangkatnya, dan Bamus Nagari di Kamang Magek Kabupaten Agam. Teknik pengumpulan data berupa penelitian lapangan dengan cara wawancara, focus group discussion ( $F G D$ ), dan studi dokumentasi dengan sumber-sumber yang valid dan akurat, dengan menggunakan teknik triangulasi metode dan triangulasi sumber data. Dalam penelitian ini teknis analisis data menggunakan langkah-langkah sebagai berikut yaitu pengumpulan data, reduksi data, penyajian data, dan penarikan kesimpulan. Tujuan dari penelitian ini adalah 
untuk mengetahui transparansi, partisipasi, dan akuntabilitas dalam pengelolaan APB Nagari di Nagari Kamang Hilia, Nagari Kamang Mudiak dan Nagari Magek Kecamatan Kamang Magek, Kabupaten Agam, Sumatera Barat.

\section{Pembahasan dan Analisa \\ 1. Pembahasan}

Implementasi Transparansi, Akuntabilitas dan Partisipasi dalam Pengelolaan APB Nagari di Kecamatan Kamang Magek, di antaranya yaitu: Pertama, implementasi prinsip transparansi khususnya di nagari kamang hilir, nagari kamang mudik, dan nagari magek pada tahap perencanaan diadakan musyawarah nagari dengan mengundang yaitu Bapak Camat Kamang Magek, Bapak Anggota DPRD Kab. Agam, Bhabinkantibmas Kamang Hilia, Bhabinsa Kamang Hilir, Ketua Bamus beserta anggota, Kepala Instansi Kecamatan, Kepala TK/SD/MTS/SMA, KAN, Ketua Lembaga Nagari, Wali Jorong, Tim Verifikasi RKP, Tokoh Masyarakat, Organisasi Kemasyarakatan, Tenaga Ahli Pendamping Desa, Pendamping Desa, Pendamping Lokal Nagari dalam menyusun kegiatan nagari yang menjadi prioritas dalam pembangunan nagari dan penyusun Anggaran Pendapatan dan Belanja Nagari tahun anggaran 2018 dan tahun 2019 dan diinput melalui aplikasi Siskedes dan aplikasi E-Planning, , hal ini menunjukkan adanya keterbukaan dalam rapat dan keterbukaan prosedur. Sedangkan tahun 2017 belum adanya keterbukaan oleh pemerintah nagari, hal ini disebabkan belum berfungsinya lembaga nagari yang ada, tidak ada keterlibatan masyarakat karena masih diputuskan oleh tingkat jorong tanpa melalui musyawarah, dan belum adanya aplikasi EPlanning dan aplikasi Siskeudes tersebut. Selanjutnya, penyusunan anggaran ditetapkan oleh tim penyusun anggaran yaitu Wali Nagari dan perangkat nagari dan hasilnya diberitahukan kepada Bamus lalu diinformasikan pada lembaga masyarakat, hal ini menunjukkan adanya keterbukaan informasi. Sementara itu, pada tahun 2018 masyarakat diminta menyampaikan usulan terkait dengan program nagari melalui Wali Jorong setiap jorong masing-masing, lalu usulan tersebut disatukan dalam musyawarah tingkat jorong dan akan dibahas dalam Musrenbang Nagari, hal tersebut menunjukkan adanya keterlibatan peran serta masyarakat. APB Nagari ini ditetapkan Wali Nagari melalui Bamus Nagari dan Bupati Agam lalu diinformasikan kepada masyarakat dalam bentuk baliho yang dipasang selama satu tahun anggaran. Pada tahap pelaksanaan, dibentuk Tim Pelaksana Kegiatan (TPK) dan Tim Penerima Hasil (TPH) oleh pemerintah nagari dalam melaksanakan kegiatan. TPK dan TPH terdiri dari 3 orang minimal, TPK terdiri dari Kepala Seksi, Lembaga Kemasyarakatan, dan Tokoh Masyarakat, sedangkan TPH bagian dari unsur masyarakat. Nagari Kamang Mudik dan Nagari Magek, Tim Pelaksanan Kegiatan memberikan informasi setiap kegiatan yang akan dilaksanakan melalui papan kegiatan yang ditandainya, tetapi pada Nagari Kamang Hilir tidak ada informasi kegiatan yang dilaksanakan tersebut. Kegiatan yang dilaksanakan harus sesuai dengan RAB yang telah ditetapkan melalui APB Nagari, stelah itu TPK dan TPH membuat laporan pertanggungjawabannya kepada Bendahara setelah kegiatan tersebut dilaksanakan, hal tersebut sudah ada keterbukaan prosedur, informasi, dan keterlibatan peran serta masyarakat dalam tahap pelaksanaan ini.

Kedua, Implementasi prinsip partisipasi di Nagari Kamang Hilir dan Nagari Kamang Mudik pada tahap perencanaan ini sudah partisipatif melalui Rapat Musyawarah Nagari (Musna) terkait APB Nagari dan Rapat Musrenbang terkait RKP 2019 dan DU-RKP 2020 pada tahun 2019, masyarakat ikut berpartisipasi dalam merencanakan kegiatan pemerintahan nagari. Partisipasi masyarakat sudah tinggi dalam pelaksanaan kegiatan fisik pembangunan seperti pengecoran jalan dan kegiatan fisik lain sebagainya secara kerjasama, swadaya dan bergotong royong. Adanya sikap proaktif pemerintah terhadap masyarakat melalui pengusulan kegiatan nagari oleh masyarakat langsung melalui Wali Jorong. Sementara itu, di Nagari Magek yang berpartisipasi ada sekitar $70-80 \%$ setiap program pemerintah seperti pelatihanpelatihan, pembinaan, pemberdayaan, dan pembangunan yang diberikan oleh pemerintah nagari.

408 Lembaga Penelitian dan Penerbitan Hasil Penelitian Ensiklopedia $\quad$ E-ISSN: 2657-0300

P-ISSN: 2657-0319 
Ketiga, Implementasi prinsip akuntabilitas sudah akuntabel dalam tahap perencanaan di Kecamatan Kamang Magek, pemerintah nagari wajib mempertanggung jawabkan RPJM Nagari ini kepada masyarakat, RPJM Nagari ini sebagai pedoman dalam membuat dokumen perencanaan tahunan nagari melalui RKP Nagari, diantaranya dalam perencanaan, penganggaran, pelaksanaan dan pengawasan. Pemerintah nagari juga wajib mempertanggungjawabkan pelaksanaan RKP Nagari yang telah disusun, menjadi acuan pembuatan RAPB Nagari oleh Sekretaris nagari, hal tersebut menunjukkan adanya akuntabilitas proses dan akuntabilitas program dari penyusunan RKP Nagari dan RAPB Nagari. Pada tahap pelaksanaan ini TPK dan TPH sudah melaksanakan kegiatan pemerintah nagari sesuai dengan RAB Nagari yang telah ditetapkan, pelaksanaan tersebut sudah baik dilaksanakan pada tahun 2018 dengan realisasi 70\% untuk kegiatan fisik dan 30\% untuk pemberdayaan, sedangkan pelaksanaan kegiatan tahun anggaran tahun 2019 ini masih dilaksanakan dalam bentuk kegiatan fisik, hal ini menunjukkan ada pertanggungjawaban kebijakan dalam pengelolaan APB Nagari di Kecamatan Kamang Magek, Kabupaten Agam.

\section{Analisa}

Pertama, Implementasi transparansi dalam pengelolaan Anggaran Pendapatan dan Belanja Nagari di Kecamatan Kamang Magek, berdasarkan hasil analisis data yang telah di paparkan di atas telah menerapkan indikator transparansi seperti yang dikemukakan oleh Halim \& Iqbal (2012), terdapat keterbukaan rapat, keterbukaan informasi keterbukaan prosedur dan keterlibatan peran serta masyarakat pada tahap perencanaan dan pelaksanaan, tetapi tahap penatausahaan, $\mathrm{p}(\mathrm{H}$. Setiawan \& Santoso, 2013)elaporan dan pertanggungjawaban masih belum transparan dilakukan pemerintah nagari di Kabupaten Agam. Pada tahap perencanaan ini masih belum transparan dalam penyusunan anggaran kegiatan tersebut dikarenakan belum ada keterlibatan peran serta masyarakat, hal ini dilakukan oleh Wali Nagari dan perangkat lainnya melalui kesepakatan Bamus Nagari. Sedangkan tahap pelaksanaan masih belum transparan dalam laporan pertangungjawaban TPK dan TPH pada Bendahara karena belum juga ada keterlibatan peran serta masyarakat dan belum ada keterbukaan informasi khususnya di Nagari Kamang Hilir dalam pelaksanaan kegiatan. Sementara itu, tahap penatausahaan, pelaporan dan pertanggungjawaban ini belum transparan dikarenakan belum juga ada keterlibatan peran serta masyarakat, tetapi tahap pertanggungjawaban sudah ada informasi laporan realisasi pelaksanaan APB Nagari melalui baliho yang dipasang di Kantor Wali Nagari.

Kedua, Implementasi Partisipasi dalam pengelolaan Anggaran Pendapatan dan Belanja Nagari di Kecamatan Kamang Magek, berdasarkan hasil analisis data yang telah dipaparkan di atas bahwa pemerintah nagari telah menerapkan indikator partisipasi yang dikemukakan oleh Hendriadi dalam Taufik (2015), terdapat partisipasi aktif publik dan sikap proaktif pemerintah pada tahap perencanaan dan pelaksanaan tetapi dalam tahap ini masih belum ada tempat kontrol lembaga dan masyarakat dalam pengelolaan APB Nagari tersebut, sedangkan pada tahap penatausahaan, pelaporan, dan pertanggungjawaban ini juga belum partisipatif dikarenakan tahapan tersebut hanya dilakukan oleh Bendahara, Wali Nagari, dan Camat Kamang Magek, tetapi dalam pelaporan pertanggungjawaban ini akan diinformasikan kepada masyarakat.

Ketiga, Implementasi akuntabilitas dalam pengelolaan Anggaran Pendapatan dan Belanja Nagari di Kecamatan Kamang Magek, berdasarkan hasil analisis data wawancara dan FDG yang telah sesuai indikator akuntabilitas menurut Ellwood dalam Abdul Khaidir (2017:239), terdapat kejujuran dan akuntabilitas hukum, akuntabilitas proses, akuntabilitas program, dan pertanggungjawaban kebijakan pada tahap perencanaan dan pelaksanaan, tetapi tahap penatausahaan, pelaporan, dan pertanggungjawaban belum akuntabel dalam pengelolaan APB Nagari tersebut. Dilihat dari laporan rekapitulasi realisasi pelaksanaan APB Nagari tahun anggaran 2018 di Kecamatan Kamang Magek dengan Anggaran sekitar Rp. 6.358.996.00, dengan realisasinya sekitar Rp. 5.952.569.577 dan persentase 93,6\%, hal tersebut menunjukkan masih ada kegiatan nagari yang belum dilaksanakan. Selanjutnya, pelaporan 
pertanggungjawaban yang dilakukan masih ada keterlambatan dalam pelaporannya sehingga belum adanya kejujuran dan akuntabilitas hukum khususnya di Kecamatan Kamang Magek, Kabupaten Agam. Sesuai dalam RKP Nagari Magek terdapat pelaporan realisasi pelaksanaan APB Nagari tahun anggaran 2018 ini dengan SILPA 0\%, jadi kegiatan-kegiatan yang direncanakan tersebut sudah terealisasi dengan baik hal ini menunjukkan sudah ada pertanggungjawaban kebijakan, sedangkan Nagari Kamang Hilir dan Nagari Kamang Mudik terdapat SILPA $284,1 \%$ dan 480,2\%, hal ini belum sesuai dengan kegiatan yang dilaksanakan tersebut belum terealisasi dengan baik, jadi hal tersebut menunjukkan belum ada pertanggungjawaban kebijakan nagari tersebut.

Sesuai penelitian Anggraeni Yunita and Christianingrum terdapat 5 (lima) prinsip yang dikembangkan oleh UNDP, yaitu transparansi, pertanggungjawaban, pengendalian, pertanggungjawaban, dan daya tanggap. Berdasarkan hasil penelitian, pelaksanaan pengelolaan dana desa di Kabupaten Bangka dari indikator yang diuraikan dalam lima prinsip tersebut, telah dilaksanakan dengan baik oleh pejabat desa sebagai pengelola program pendanaan desa, hal tersebut tidak sesuai dengan teorinya Ellwood dalam Abdul Khaidir, terdapat 4 (empat) indikator yang diuraikan belum dilaksanakan dengan baik di Kecamatan Kamang Magek, Kabupaten Agam.

\section{Penutup}

Berdasarkan hasil pembahasan yang telah dilakukan penulis maka dapat ditarik kesimpulan yaitu implementasi prinsip transparansi, akuntabilitas dan partisipasi dalam pengelolaan APB Nagari di Kecamatan Kamang Magek belum sepenuhnya terimplementasi dengan baik, khususnya di Nagari Kamang Mudik, Nagari Kamang Hilir dan Nagari Magek. Pertama, Implementasi prinsip transparansi dalam pengelolaan Anggaran Pendapatan dan Belanja Pemerintahan Nagari di Kecamatan Kamang Magek sudah transparan pada tahap perencanaan dan tahap pelaksanaan terdapat keterbukaan informasi, keterbukaan prosedur, keterbukaan rapat-rapat, dan adanya keterlibatan peran serta masyarakat, tetapi, pada tahap penatausahaan, pelaporan dan pertanggungjawaban belum transparan. Kedua, Implementasi prinsip partisipasi dalam pengelolaan Anggaran Pendapatan dan Belanja Pemerintahan Nagari di Kecamatan Kamang Magek sudah partisipasi dalam tahap perencanaan dan pelaksanaan, terdapat partisipasi aktif publik dalam perumusan program, adanya peraturan yang memberikan tempat kontrol masyarakat, dan adanya sikap proaktif pemerintah dalam mendorong partisipasi masyarakat dalam proses penganggaran, tetapi dalam tahap penatausahaan, pelaporan dan pertanggungjawaban belum partisipatif. Ketiga, Implementasi prinsip akuntabilitas dalam pengelolaan Anggaran Pendapatan dan Belanja Pemerintahan Nagari di Kecamatan Kamang Magek sudah akuntabilitas dalam tahap perencanaan dan pelaksanaan terdapat kejujuran dan akuntabilitas hukum, akuntabilitas proses, akuntabilitas program, dan pertanggungjawaban kebijakan, tetapi belum akuntabel dalam tahap penatausahaan, pelaporan, dan pertanggungjawaban. Jadi, implementasi prinsip transparan, akuntabilitas dan partisipasi dalam pengelolaan Anggaran Pendapatan dan Belanja Pemerintahan Nagari di Kabupaten Agam belum berjalan dengan baik sesuai dengan aturannya, sehingga penulis dapat menyarankan: 1) Harus ada regulasi yang jelas dalam Peraturan Bupati Agam dalam pengelolaan APB Nagari di Kecamatan Kamang Magek; 2) Harus ada pelatihan dan pembinaan secara intensif dalam pengelolaan keuangan nagari di Kecamatan Kamang Magek; 3) Harus ada sosialisasi program-program pemerintah nagari secara berkelanjutan dalam pelaksanaan kegiatan nagari di Kecamatan Kamang Magek; 4) Harus ada perekrutan pegawai yang berkompeten dan pengetahuan yang luas di bidang akuntansi dan bidang teknik sipil di di Kecamatan Kamang Magek; dan 5) Harus ada pengawasan yang jelas dan diatur dalam Peraturan Bupati Agam di Kabupaten Agam. 


\section{Dafar Pustaka}

Agustin, H., Arza, F. I., Mulyani, E., \& Fitra, H. (2017). Potret Pertanggung Jawaban Dan Pelaporan Dan Keuangan Nagari Di Kabupaten Pasaman Barat. Wahana Riset Akuntansi, 5(2), 1019-1028. Retrieved From Http://Ejournal.Unp.Ac.Id/Index.Php/Wra/Article/View/8729

Alfasadun, Hardiningsih, P., Ratnasari, Sri Devi, \& Srimindarti, C. (2018). Transparansi Dan Akuntabilitas Pengelolaan Dana Desa. Prosiding Sendi_U, (4), 684-691. Retrieved From Https://Www.Unisbank.Ac.Id/Ojs/Index.Php/Sendi_U/Article/View/6051

Armaini, R. (2017). Asas-Asas Pengelolaan Keuangan Desa Dalam Pencapaian Akuntabilitas Penggunaan Dana Desa Di Desa Karang Agung Kabupaten Pali. Jurnal Acsy: Jurnal Accounting Politeknik Sekayu, 6(1), 57-67. Retrieved From Https://Jurnal.Polsky.Ac.Id/Index.Php/Acsy/Article/View/41

Assyahri, W., \& Vaguita, M. (2019). Evaluasi Penggunaan Aplikasi Sistem Keuangan Desa (Siskeudes) Di Nagari Kayu Tanam Kecamatan 2x11 Kayu Tanam. Nakhoda: Jurnal Ilmu Pemerintahan, 18(2), 79-91. Retrieved From Https://Nakhoda.Ejournal.Unri.Ac.Id/Index.Php/Njip/Article/View/91

Astuti, T. P., \& Yulianto, Y. (2016). Good Governance Pengelolaan Keuangan Desa Menyongsong Berlakunya Undang-Undang No. 6 Tahun 2014. Berkala Akuntansi Dan Keuangan Indonesia, 1(1), 1-15. Retrieved From Http://EJournal.Unairac.Id/Baki/Article/View/1694

Atmadja, A. T., \& Saputra, K. A. K. (2018). Determinant Factors Influencing The Accountability Of Village Financial Management. Academy Of Strategic Management Journal, 17(1). Retrieved From Http://Www.Researchgate.Net/Publication/324129289_Determinant_Factors_Influencing _The_Accountability_Of_Village_Finance_Management

Halim, A., \& Iqbal, M. (2012). Pengelolaan Keuangan Daerah. Yogyakarta: Andi Offset.

Kadir, A., Widarini, K. N., Gunawan, D. I., \& Puspitasari, D. (2017). The Indonesian Perspectives On Village Financial Management Accountability. International Journal Of Economics, Business And Management Research, 1(04), 234-251. Retrieved From Http://Ijebmr.Com

Leonardo Yosua Liando, Lambey, L., \& Wokas, H. R. . (2017). Analisis Pengelolaan Dan Pertanggungjawaban Anggaran Pendapatan Dan Belanja Desa Di Desa Kolongan Kecamatan Kombi Kabupaten Minahasa. Jurnal Emba: Jurnal Riset Ekonomi, Manajemen, Bisnis Dan Akuntansi, 5(2), 1474-1483. Retrieved From Https://Ejournal.Unsrat.Ac.Id/Index.Php/Emba/Article/View/16214

Meutia, I., \& Liliana. (2017). Pengelolaan Keuangan Dana Desa. Jurnal Akuntansi $\begin{array}{llll}\text { Multiparadigma, } & \text { 8(2), } & \text { 336-352. } & \text { Retrieved }\end{array}$ Https://Jamal.Ub.Ac.Id/Index.Php/Jamal/Article/View/645

Sartika, D., \& Nini. (2018). Akuntabilitas Dan Transparansi Alokasi Dana Desa (Add) Pada Nagari Labuah Gunuang. Jurnal Ekonomi \& Bisnis Dharma Andalas, 20(1), 26-40. Retrieved From Http://Ojs.Unidha.Ac.Id/Index.Php/Edb_Dharmaandalas/Article/View/76

Setiawan, A. (2018). Pengelolaan Alokasi Dana Desa Dalam Mewujudkan Good Governance. Among Makarti: Journal Of Economics \& Business, 11(2), 23-36. Retrieved From Https://Jurnal.Stieama.Ac.Id/Index.Php/Ama/Article/View/165

Setiawan, H., \& Santoso, P. (2013). Model Optimalisasi Peluang Pemanfaatan Media Jejaring Sosial Dalam Implementasi E-Governance Di Indonesia. Jurnal Informatika. Upn "Veteran" Yogyakarta., 2013(Semnasif), 147-154.

Shuha, K. (2018). Analisis Pengelolaan Dana Desa (Studi Kasus Pada Desa-Desa Selingkungan Kecamatan Lubuk Alung Kabupaten Padang Pariaman). Universitas Negeri Padang, 6(2), 1-21. Retrieved From Http://Ejournal.Unp.Ac.Id/Students/Index.Php/Akt/Article/View/3787

Supriadi, E. (2015). Pertanggungjawaban Kepala Desa Dalam Pengelolaan Keuangan Desa 
Berdasarkan Undang-Undang Nomor 6 Tahun 2014 Tentang Desa. Jurnal Ius: Kajian Hukum Dan Keadilan, 3(8), 330-346. Retrieved From Https://Jurnalius.Ac.Id/Ojs/Index.Php/Jurnalius/Article/View/216

Vaguita, M., \& Adnan, M. F. (2019). Inhibited Factors In Management Government Finance Of Nagari: Case Study In Nagari Kamang Hilir, Kamang Magek Subdistrict, Agam Regency. 9(2), 256-264. Retrieved From Https://Journal.Uinsgd.Ac.Id/Index.Php/Jispo/Article/View/5392

Yulihantini, D. T., \& Wardayanti, S. M. (2016). Financial Accountability In The Management Of Village Fund Allocation. The 1st International Conference On Business And Accounting Studies, 359, 359-366. Retrieved From Http://Repository.Unej.Ac.Id/Handle/123456789/79240

Yunianti, U. (2015). Analisis Efisiensi Dan Efektivitas Anggaran Pendapatan Dan Belanja Desa (Apbdesa). Seminar Nasional Pgri Yogyakarta, 499-503. Retrieved From Http://Repository.Upy.Ac.Id/334/

Undang-Undang Nomor 6 Tahun 2014 Tentang Desa.

Peraturan Menteri Dalam Negeri Republik Indonesia Nomor 113 Tahun 2014 Tentang Pengelolaan Keuangan Desa.

Peraturan Bupati Kabupaten Agam Nomor 29 Tahun 2018 Tentang Pedoman Penyusunan Anggaran Pendapan Dan Belanja Nagari Tahun Anggaran 2019. 